INTENSIF, Vol.4 No.2 August 2020

ISSN: 2580-409X (Print) / 2549-6824 (Online)

DOI: https://doi.org/10.29407/intensif.v4i2.14297

\title{
ITSM Strategy Using CSI on ITIL V.3 to Improve IT Services
}

Strategi ITSM Menggunakan CSI Pada ITIL V.3 Untuk Meningkatkan Layanan TI

Received:

3 March 2019

Accepted:

13 July 2020

Published:

19 August 2020

\author{
1* Khurotul Aeni, ${ }^{2}$ Randi Adzin M \\ ${ }^{1,2}$ Teknik Informatika, Teknik Elektro Universitas Peradaban \\ ${ }_{1,2}$ Brebes, Indonesia \\ E-mail: ${ }^{1}$ khaeni988@gmail.com, ${ }^{2}$ randi.adzin.m@gmail.com \\ *Corresponding Author
}

\begin{abstract}
The SIMBARU (Academic information System) developed by PUKSI (Computer Center and Information systems) can manage academic activities. The obstacles that currently occur in the SIMBARU process is how to utilize an IT-based educational service system. It is ready to run/use in the optimal time optimally, providing services with the right target, fast access that can provide satisfaction to users (user), and the vision of mission and institutional business objectives can be realized. Using the PDCA data analysis Method (Plan, Do, Check, and ACT), it is expected to design a SIP document (Service Improvement Plan) to improve the performance of SIMBARU. The design of SIP documents on SIMBARU can be done by using IT Infrastructure Library V. 3 by analyzing the condition of SIMBARU, which then produces output in the form of SIP. The results of this research SIP designed under the knowledge gained from the analysis results can be used as a strategy to improve IT services in college, which resulted in the recommendation of improvement and output in the form of SIP. Repair and SIP recommendations are expected to improve IT services so that the IT service, i.e., SIMBARU can help the academic staff conduct academics in a college.

Keyword-Peradaban University, IT Infrastructure Library V.3, Service Improvement Plan (SIP), PDCA(Plan, Do, Check, and Act)

Abstrak-SIMBARU (Sistem Informasi Akademik) yang dikembangkan oleh PUKSI (Pusat Komputer dan Sistem Informasi) dapat digunakan untuk mengelola kegiatan akademik. Kendala yang saat ini terjadi pada proses SIMBARU adalah bagaimana cara untuk memanfaatkan system layanan akademik berbasis IT yang siap dijalankan/dipakai dalam waktu yang berkepanjangan secara optimal, menyediakan layanan dengan tepat sasaran, akses yang cepat dimana bisa memberikan kepuasan kepada pengguna (user), serta visi misi dan tujuan bisnis institusi bisa terwujud. Dengan menggunakan metode analisa data PDCA (Plan, Do, Check, and Act), dengan langkah analisis CSF terlebih dahulu, analisis SWOT, dan survei kepuasan pengguna, serta hasil analisis SIMBARU, berhasil membuat rekomendasi berupa perancangan dokumen SIP dengan menggunakan ITIL V.3, rekomendasi SIP (Service Improvement Plan), dapat diimplementasikan guna meningkatkan layanan TI pada perguruan tinggi dalam waktu jangka panjang, sehingga visi, misi, dan tujuan bisnis instutusi dapat terwujud.
\end{abstract}

Kata Kunci-Universitas Peradaban, IT Infrastructure Library V.3, Service Improvement Plan (SIP), PDCA (Plan, Do, Check, and Act)

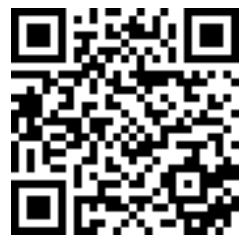


INTENSIF, Vol.4 No.2 August 2020

ISSN: 2580-409X (Print) / 2549-6824 (Online)

DOI: https://doi.org/10.29407/intensif.v4i2.14297

\section{INTRODUCTION}

An organization or agency must pay attention to satisfying services to its users, which is no less important to pay attention to are IT-based services, such as IT-based academic services in universities. It is the main activity in service to run correctly and efficiently. The current obstacle is how to take advantage of an IT-based educational service system that is ready to run [1]. To improve skills in service in higher education, and service efficiency to users, optimal planning is needed, one of which is by implementing IT Service Management (ITSM). [2]. Information technology services are also needed in the long term to be adequately utilized by its users. At the implementation stage, there are sometimes problems that usually arise, disrupting services that impact users. By exploring new approaches [3] applying the concept of Continual Service Improvement (CSI), which can be used by an organization/institution to improve and maximize information technology services, optimize service costs and underlie the Information Technology Service Management (ITSM) process.

In previous research by Fransiska [4], the implementation of ITSM using ITIL V.3 was able to design incident management and problem management in-service operation and create standard operating procedures (SOPs) based on the results of the network assessment system and IT service infrastructure. In another study [5] and [6] examined the functions of IT service management and architectural frameworks as an interconnected framework, where the results between the service-oriented architecture (SOA) and the information technology infrastructure library (ITIL) have an interrelated model in complementary IT services. Unlike what was done by Fransiska [4], the implementation of ITSM in ITIL V.3 in this study emphasizes the use of CSI. It is done because the SIMBARU academic information system requires a prolonged plan for optimal service.

The CSI (Continual Service Improvement) expects to improve IT services at SIMBARU, which helps academic staff carry out academic activities in higher education. CSI itself is a formal plan containing guidelines and recommendations for carrying out improvements and enhancing IT services, which contains policies that have been mutually agreed upon by stakeholders. Ari Wedhaswara emphasized that implementing a standard service management system can be done by identifying and managing the entire work process and interacting internally and externally. This Continual Service Improvement will be combined with a strategic design concept under the needs of the organization. Several concepts of thought are often referred to by logically ordered methods and have advantages over one another. The Continual Service Improvement System used by the Civilization University is the Information Technology Infrastructure Library Framework V.3 (ITIL). 


\section{RESEARCH METHOD}

\section{A. Information Systems / Information Technology Strategy}

Earl (1997) [7] states that the SI strategy answers the question of "what?" in determining the SI application required by an organization. In contrast to the IT strategy, it is more to answer the question of "how?" in choosing infrastructure, technology. Various IS / IT strategies have now been developed, one of which is by [5], [8], and [9] who have succeeded in achieving their goals and benefits in assessing the ITIL process using ITSM.

\section{B. IT Infrastructure Library V.3 Service Lifecycle}

ITIL (IT Infrastructure Library) provides a best practice framework for IT Service Management, ITIL has grown and become the most widely used framework for IT service management. The description of "ITIL V.3 - Service Lifecycle Introduction": [10] [11]

1. Service Strategy

2. Service Design

3. Service Transition

4. Service Operation

5. Continual Service Improvement

The implementation of ITIL V.3 and CSI used in various fields / organizations, such as PT's problems.Telkom MSC East Java Area [12], a university / college [13] , an organization [14] [15] [16], health [17], even governance [18] [19] [20]. The ITIL V.3 cycle can be seen in Figure 1.

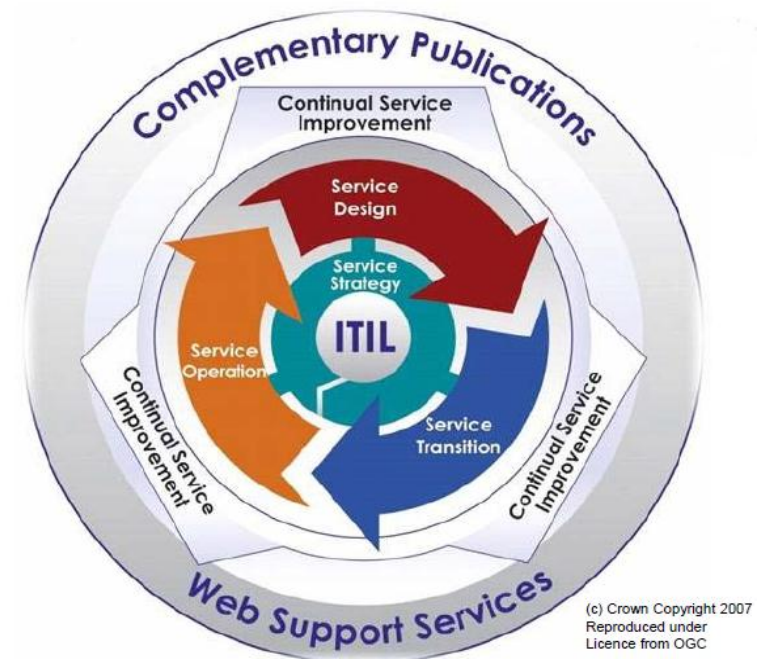

Figure 1. ITIL V.3 Cycle [10] 
INTENSIF, Vol.4 No.2 August 2020

ISSN: 2580-409X (Print) / 2549-6824 (Online)

DOI: https://doi.org/10.29407/intensif.v4i2.14297

\section{PDCA Cycle}

In the SIP design process, the PDCA cycle (Plan, Do, Check, and Act). Walter Shewhart introduced this method in 1930, known as the "Shewhart Cycle," which was later developed by Dr. Walter Edwards Deming in 1980, better known as "The Deming Wheel." This method is useful for making improvements to the system by having a curtain work pattern. The PDCA cycle has four stages, as shown in Figure 2. [20]

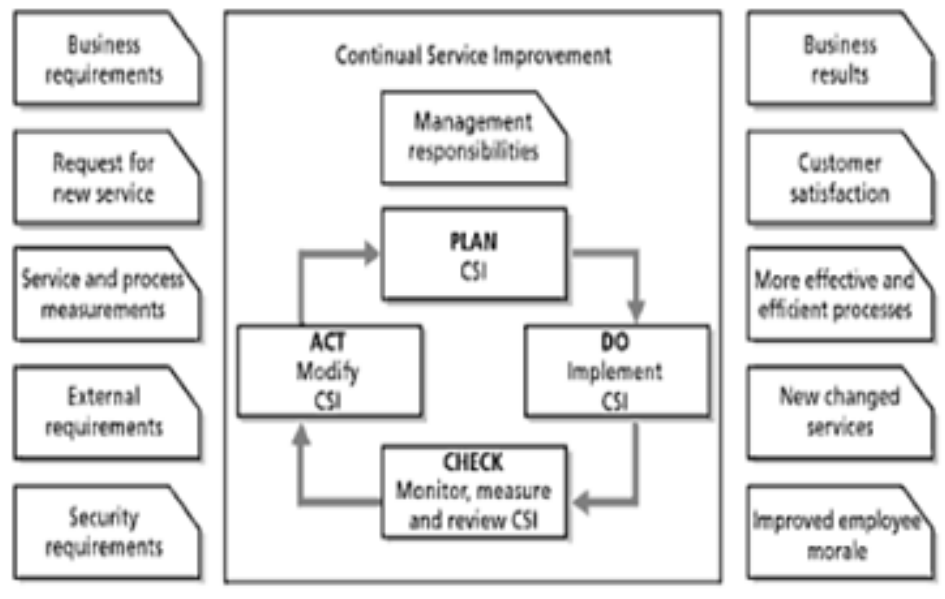

Figure 2. PDCA CYCLE

The explanation of the PDCA cycle method is in Figure 2, below:

At the Plan stage, is the stage for identifying and analyzing problems. There are two steps in this Plan stage; the first is Identify the strategy for improvement, which can be used to identify the organization's vision, business needs, organizational strategy, and organizational goals. The second step Defines what should be measured; this step relates to the strategy, objectives that have been set in measuring service, service process management, and the technology required. This stage can be done by measuring customer satisfaction surveys.

At the Plan stage, is the stage for identifying and analyzing problems. There are two steps in this Plan stage; the first is Identify the strategy for improvement, which can be used to identify the organization's vision, business needs, organizational strategy, and organizational goals. The second step Defines what you should measure; this step relates to the strategy, objectives that have been set in measuring service, service process management, and the technology required. This stage can be done by measuring customer satisfaction surveys.

The third stage is Check; this stage is carried out to find weaknesses that must be corrected from the information that has been obtained from stage Do. The first step is to analyze the information and data, meaning that when the data has en processed into information, it can be done to analyze the problems that occur and what changes and improvements are needed. The 
INTENSIF, Vol.4 No.2 August 2020

ISSN: 2580-409X (Print) / 2549-6824 (Online)

DOI: https://doi.org/10.29407/intensif.v4i2.14297

second step is Present and uses the information after the information has been analyzed; it will be converted into knowledge prepared in SIP (Service Improvement Plan).

The fourth stage is the last in the PDCA cycle, namely Act, this stage describes the steps in implementing improvement. The next step determines how to implement SIP based on the check stage results and carry out the overall plan for improvement and improvement when weaknesses have been found.

\section{RESULT AND DISCUSSION}

The flow of this research can be seen in Figure 3.

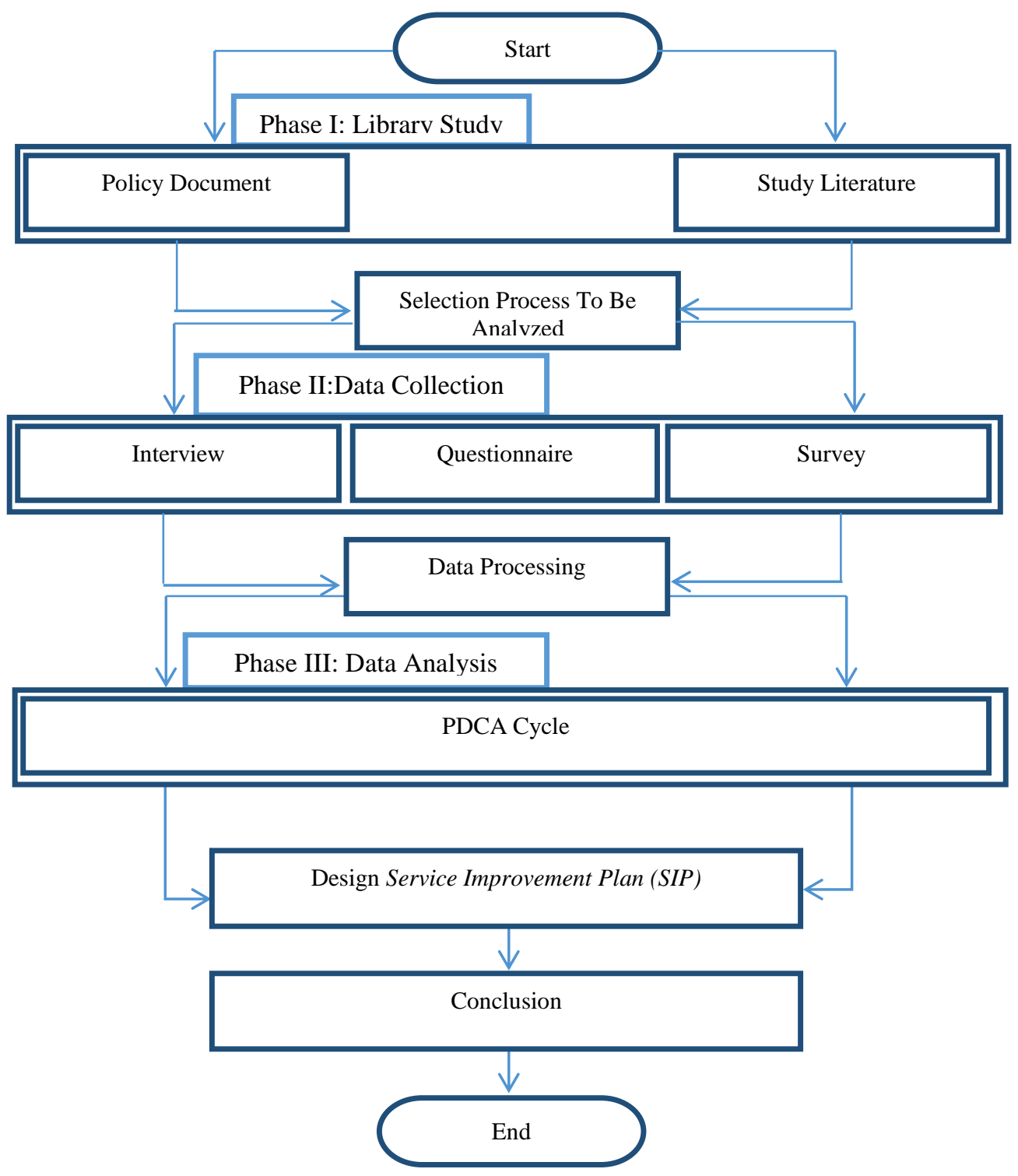

Figure 3. STAGES OF RESEARCH 
INTENSIF, Vol.4 No.2 August 2020

ISSN: 2580-409X (Print) / 2549-6824 (Online)

DOI: https://doi.org/10.29407/intensif.v4i2.14297

The research carried out can be completed with a research flow divided into several stages, as in Figure 3:

1. Phase I: Literature study, at this stage it is t to find references by the concept to be used by the following steps: a) Studying the strategic plan (strategic plan) document for higher education IT management; b) Policy management on the application of academic information systems (SIMBARU); c) Learn about the concepts, theory of ITIL V.3, CSI, ITSM, related journals or reports.

2. Phase II: Data collection. The next stage, the second stage in this study, namely data collection using interviews/interviews and observations/surveys. The primary data needed to assist in completing this research were from the object of research by conducting interviews with PUKSI managers. Interviews were conducted using the guided interview method, where questions were asked to informants according to a list of questions previously made. The human resource in this study was the Head of the PUKSI section in higher education. The data obtained from observations and interviews on May 5, 2019, is an overview of PUKSI's section, PUKSI's vision and mission, PUKSI's business plans and business strategies, the purpose of SIMBARU, SIMBARU Business Processes. The interview on May 10, 2019, produced data in the form of CSF (Critical Success Factor) and SWOT (Strength, Weakness, Opportunities, Threat) analysis in the college's IT environment. For CSF (Critical Success Factor) analysis, a strategy for SIMBARU is generated, which can be seen in Table 1. Critical Success Factor.

Table 1. CSF (CRITICAL SUCCESS FACTOR)

\begin{tabular}{|c|c|c|}
\hline Objective/ Goal & CSF Candidate & $\begin{array}{c}\text { KPI (Key Performance } \\
\text { Indicators) }\end{array}$ \\
\hline $\begin{array}{l}\text { Minimizing the time and } \\
\text { costs required by students } \\
\text { when carrying out the } \\
\text { academic process }\end{array}$ & $\begin{array}{l}\begin{array}{l}\text { Managing the NEW SIM } \\
\text { related } \\
\text { problems/problems } \\
\text { occur }\end{array} \\
\text { that } \\
\end{array}$ & $\begin{array}{l}\text { SIMBARU can be accessed } \\
24 \text { hours a day. }\end{array}$ \\
\hline $\begin{array}{l}\text { Facilitate the performance of } \\
\text { academic staff }\end{array}$ & $\begin{array}{l}\text { Users perform their jobs } \\
\text { under the job desk, obey the } \\
\text { rules, and impose sanctions } \\
\text { for users who do not comply } \\
\text { with the rules. }\end{array}$ & 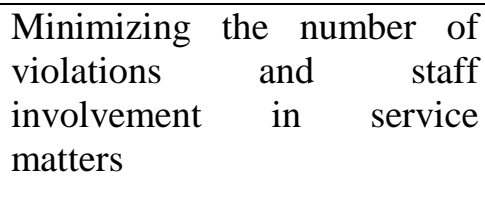 \\
\hline
\end{tabular}

3. Stage III: Data Analysis

At this stage using the PDCA cycle method:

At the Plan stage, the results obtained are in the form of analysis of problems in SIMBARU at this time; the first step of the planning stage is to identify the strategy for improvement. The 
INTENSIF, Vol.4 No.2 August 2020

ISSN: 2580-409X (Print) / 2549-6824 (Online)

DOI: https://doi.org/10.29407/intensif.v4i2.14297

process that occurs in SIMBARU that must be obeyed by its users can be seen in Table 2 . Process in SIMBARU.

Table 2. SIMBARU PROCESS

\begin{tabular}{|c|c|c|c|c|c|}
\hline No & Service Name & $\begin{array}{c}\text { Person in } \\
\text { charge }\end{array}$ & Service Description & Related Services & $\begin{array}{l}\text { Period } \\
\text { (Time) }\end{array}$ \\
\hline 1 & $\begin{array}{l}\text { Admission of } \\
\text { new students }\end{array}$ & $\begin{array}{l}\text { Student Affairs } \\
\text { (PPMB) }\end{array}$ & $\begin{array}{l}\text { Conducting a } \\
\text { selection of } \\
\text { prospective students } \\
\text { who will be accepted }\end{array}$ & $\begin{array}{l}\text { Student } \\
\text { registration in the } \\
\text { Academic and } \\
\text { Finance sections }\end{array}$ & $\begin{array}{l}\text { According to } \\
\text { the set time }\end{array}$ \\
\hline 2 & $\begin{array}{l}\text { Student } \\
\text { Registration }\end{array}$ & Finance & $\begin{array}{l}\text { Manage the data of } \\
\text { students who pass the } \\
\text { new student } \\
\text { admission selection }\end{array}$ & Payment invoice & One semester \\
\hline 3 & $\begin{array}{l}\text { New Student } \\
\text { Registration }\end{array}$ & Academic & $\begin{array}{l}\text { Manage accepted } \\
\text { student data }\end{array}$ & $\begin{array}{l}\text { Trusteeship, } \\
\text { course } \\
\text { registration, } \\
\text { lecture room, } \\
\text { lecture schedule }\end{array}$ & One semester \\
\hline 4 & Trusteeship & PA lecturer & $\begin{array}{l}\text { The lecturer briefs the } \\
\text { students }\end{array}$ & $\begin{array}{l}\text { Course } \\
\text { registration }\end{array}$ & One semester \\
\hline 5 & Lecture room & Sarpras & $\begin{array}{l}\text { Arranging space for } \\
\text { lecture activities }\end{array}$ & Class schedule & One semester \\
\hline 6 & Tuition bill & Finance & $\begin{array}{l}\text { Set the number of } \\
\text { bills that must be paid } \\
\text { by students }\end{array}$ & Related bank & One semester \\
\hline 7 & $\begin{array}{l}\text { Payment of } \\
\text { college bills }\end{array}$ & Related bank & $\begin{array}{l}\text { Handling student bill } \\
\text { payment processes }\end{array}$ & $\begin{array}{l}\text { Course } \\
\text { registration }\end{array}$ & One semester \\
\hline
\end{tabular}

The second step of the Plan stage is to define what will be measured. SWOT analysis can be used to determine the current state of SIMBARU. The results of the SWOT analysis can be used to determine the material to measure SIMBARU's performance for the results of the SWOT analysis can be seen in Table 3. SWOT.

Table 3. SwOT

\begin{tabular}{|c|c|c|c|}
\hline Strength & Weakness & Opportunities & Threat \\
\hline $\begin{array}{l}\text { SIMBARU is an } \\
\text { online information } \\
\text { system so that it can } \\
\text { be accessed } 24 \text { hours } \\
\text { anywhere and } \\
\text { anytime with an } \\
\text { internet connection. }\end{array}$ & $\begin{array}{l}\text { There are delays and } \\
\text { service buildup } \\
\text { when many users } \\
\text { access SIMBARU. }\end{array}$ & $\begin{array}{l}\text { The technology used } \\
\text { by SIMBARU can } \\
\text { still be developed } \\
\text { according to current } \\
\text { technological } \\
\text { developments. }\end{array}$ & $\begin{array}{l}\text { The condition of } \\
\text { electricity service in } \\
\text { Univ. Civilization is not } \\
\text { stable; there are still } \\
\text { frequent blackouts that } \\
\text { disturb the running of } \\
\text { the SIMBARU server. }\end{array}$ \\
\hline
\end{tabular}

The second stage is Do, for the first step is to gather the data; this step is used to collect user satisfaction survey data; the instrument used is the SERVQUAL (service quality) instrument. Satisfaction indicators can be seen in Table 4. satisfaction Indicators. 
Table 4. SATISFACTION INDICATORS

\begin{tabular}{lll}
\hline \hline Satisfaction Measure & \multicolumn{1}{c}{ Penjelasan } & \multicolumn{1}{c}{ Indicators } \\
\hline Tangibles & $\begin{array}{l}\text { Regarding the physical } \\
\text { appearance of the NEW SIM, } \\
\text { the services provided, and the } \\
\text { management of SIMBARU. }\end{array}$ & $\begin{array}{l}\text { The function of using the } \\
\text { SIMBARU application. }\end{array}$ \\
\hline Reliability & $\begin{array}{l}\text { Regarding the ability of the } \\
\text { SIMBARU application is to } \\
\text { respond (convey) information } \\
\text { accurately to users. }\end{array}$ & $\begin{array}{l}\text { Deliver information accurately } \\
\text { on the matching of courses } \\
\text { taken with the tuition fees paid. }\end{array}$ \\
& $\begin{array}{l}\text { Regarding the ability of the } \\
\text { SIMBARU application to } \\
\text { respond (respond to) requests } \\
\text { promptly to the user. }\end{array}$ & $\begin{array}{l}\text { The timeliness of the } \\
\text { SIMBARU application service } \\
\text { in providing information when } \\
\text { an error/problem occurs. }\end{array}$ \\
\hline Regarding the SIMBARU \\
application in ensuring the & $\begin{array}{l}\text { SIMBARU can be accessed } \\
\text { anytime and anywhere, } \\
\text { trust of its users. }\end{array}$ & $\begin{array}{l}\text { ensuring the security of the } \\
\text { user's identity. }\end{array}$ \\
\hline
\end{tabular}

The second step of the Do stage is to process the data. The sample consists of 60 students consisting of 4 faculties, of which there are 15 people for each faculty. Which then tested the validity of the statements in the questionnaire that had been distributed. Based on the validity test results, the conclusion is that the type of statement in the questionnaire is valid, provided that the value of $r$ (count) $\geq r$ (table). With a table of $r$ value (table) of $4 \%$ with a sample size of 60 people, the r-value (table) is 0.11 . As for reliability, it can be seen if the value of $\alpha>0.6$, where the result is the value of $\alpha=0.74$ and is more significant than 0.6 , then the questionnaire is declared reliable.

The third stage is Check, for the first step, Analyze the information and data. This step can be done when the Do stage has been completed. The result that the questionnaire statement has been said to be valid and reliable. In Analyze the information and data, use analysis on SIMBARU is carried out. The results can be seen in Table 5.The results of the analysis using SIMBARU are then calculated using a Likert scale on each questionnaire statement.

Table 5. SIMBARU ANALYSIS RESUlT

\begin{tabular}{llll}
\hline \hline No & \multicolumn{1}{c}{ Statements } & Result & \multicolumn{1}{c}{ Information } \\
\hline 1 & Ease of use SIMBARU & $70 \%$ & Satisfied \\
\hline 2 & $\begin{array}{l}\text { The accuracy of the information SIMBARU } \\
\text { provides to users }\end{array}$ & $65 \%$ & Satisfied \\
\hline 3 & $\begin{array}{l}\text { The match between the courses taken and the } \\
\text { tuition fees charged }\end{array}$ & 63,82 & Satisfied \\
\hline 4 & $\begin{array}{l}\text { The timeliness conveyed by SIMBARU in handling } \\
\text { errors/problems to users }\end{array}$ & $59,78 \%$ & Enough \\
\hline 5 & $\begin{array}{l}\text { SIMBARU's speed in responding to requests from } \\
\text { users }\end{array}$ & $58,77 \%$ & Enough \\
\hline 6 & Guarantee the security of user data will not be lost & $56,51 \%$ & Enough \\
\hline
\end{tabular}


The second step of the check stage is to present and use the information. From the results of the CSF analysis in table 1, SWOT in table 3, and the user satisfaction survey in table 4, and the SIMBARU analysis results in table 5, a service improvement plan can be drawn up that can be implemented to improve SIMBARU's performance. Recommendations for improvements can be presented in the form of a service improvement plan (SIP). The SIP (Service Improvement Plan) can be seen in Table 6.

Table 6. SIP (SERVICE IMPROVEMENT PLAN)

\begin{tabular}{|c|c|c|}
\hline Document : & Service Improvement Plan & \\
\hline Organization: & PUKSI & \\
\hline \multicolumn{3}{|c|}{ Goal: Improve user time efficiency SIMBARU } \\
\hline No & Action & Executor \\
\hline 1 & Users can log in more than one connection at the same time & PUKSI \\
\hline \multicolumn{3}{|c|}{ Goal: Improve quality assurance } \\
\hline No & Action & Executor \\
\hline 1 & $\begin{array}{l}\text { Provide suggestions for specialized staff handling the } \\
\text { service desk }\end{array}$ & PUKSI \\
\hline \multicolumn{3}{|c|}{ Goal: Increase awareness of PIC to update status after troubleshooting/problem } \\
\hline No & Action & Executor \\
\hline 1 & Repair IT Helpdesk application services & PUKSI \\
\hline
\end{tabular}

\section{CONCLUSION}

Based on the research carried out, it can be concluded that SIP design can be done as a way/strategy to improve IT services in higher education by implementing CSI in ITIL V.3. It can be done by analyzing CSF, SWOT, and user satisfaction surveys. With recommendations to improve SIMBARU user time efficiency, improve quality assurance, and increase PCS awareness to update status after troubleshooting/error. With this SIP, it is hoped that it can be implemented to improve IT services in tertiary institutions in the long term. 


\section{REFERENCES}

[1] I. Taufik, "PERANCANGAN IT GOVERNANCE LAYANAN AKADEMIK MENGGUNAKAN FRAMEWORK INFORMATION TECHNOLOGY INFRASTRUCTURE LIBRARY (ITIL) VERSI 3 (STUDI KASUS: UIN SGD BANDUNG)," no. 2, 2011.

[2] Nurfaizah, E. Utami, and M. R. Arief, "Rancangan Information Technology Service Management Menggunakan Information Technology Infrastructure Library (Studi Kasus : STMIK AMIKOM Purwokerto)," vol. 8, no. 2, pp. 18-31, 2015.

[3] H. Mafatihus Solehah and S. Pramono Hadi, "STRATEGI IMPLEMENTASI CONTINUAL SERVICE IMPROVEMENT MENGGUNAKAN FRAMEWORK ITIL V.3,” Semin. Nas. Teknol. Inf. dan Komun., 2014.

[4] F. Fransiska, M. Murahartawaty, and A. Karma, "Perancangan Service Operation Pada Layanan Ti Pusair Dengan Menggunakan Framework Itil Versi 3," Sisfo, vol. 05, no. 04, 2015.

[5] K. S. dan Aradea, "RANCANGAN STRATEGI LAYANAN TEKNOLOGI INFORMASI UNTUK INSTITUSI PERGURUAN TINGGI | Surendro | Seminar Nasional Aplikasi Teknologi Informasi (SNATI)," SNATI, 2011.

[6] Aradea, "Integrasi Arsitektur dan Manajemen Layanan TI untuk Pencapaian Fleksibilitas Teknologi Informasi," Semin. Nas. Apl. Teknol. Inf. (SNATI 2011), vol. 2011, no. June 2011, pp. 17-18, 2016.

[7] Ari Wedhasmara, "LANGKAH-LANGKAH PERENCANAAN STRATEGIS SISTEM INFORMASI DENGAN MENGGUNAKAN METODE WARD AND PEPPARD | Wedhasmara | Jurnal Sistem Informasi,” JSI, vol. VOL. 1, NO, pp. 14-22, 2009.

[8] Hendra, "Penerapan Best Practice IT Service Management dalam Perbaikan IT Service Desk: Studi Kasus PT. Matahari Putra Prima," ComTech Comput. Math. Eng. Appl., vol. vol 2 no 2, 2011.

[9] Melissa Indah Fianty, "Meningkatkan Kualitas Pelayanan Teknologi Informasi Menggunakan Metode DMAIC pada Divisi IT Helpdesk PT XYZ," Kalbiscientia, vol. vol.4 no.1, pp. 96-102, 2017.

[10] itSMF, An Introductory Overview of ITIL V3. 2013.

[11] Musda, "An Introductory Overview of ITIL V3 A High Level Overview of ITIL," in Itil, 2013.

[12] Y. M. M. Wahyu Setiawan, Sulistiowati, "Perencanaan Information Technology Service Continuity Management Berdasarkan ITIL V-3 Pada PT Telkom Msc Area V Jawa Timur | Setiawan | Jurnal JSIKA,” JSIKA, vol. Vol 3 No., 2014.

[13] E. K. U. Fajri Arfan, M. Teguh Kurniawan, "Penilaian dan Perancangan Tata Kelola Manajemen Layanan Teknologi Informasi Domain Service Operation Berdasarkan ISO 20000, ISO 15504 dan ITIL V3 Di Direktorat Sistem Informasi Telkom University," in e-Proceeding of Engineering, 2015, p. 7636.

[14] A. Yus, "Implementasi Continuous Improvement Dalam Organisasi," pp. 1-5.

[15] M. Agus, "Keberhasilan Bisnis salah satunya sangat dipengaruhi oleh kemampuan perusahaan dalam mengelola infrastruktur IT, tidak hanya ketersediaan infrastruktur IT saja yang disiapkan, melainkan bagaimana infrastruktur tersebut dapat digunakan dan dikelola untuk," vol. 2, 2010.

[16] F. N. Hakim and V. G. Utomo, "Perancangan Aplikasi," vol. 4, no. 2, pp. 1-9, 2015.

[17] A. Holil et al., "Berdasarkan ITIL V3 Dan COBIT 5 Pada Rumah Sakit PHC Surabaya," vol. 5, pp. 462-469, 2015.

[18] L. A. K. Wardani, M. Murahartawaty, and L. Ramadani, "Perancangan Tata Kelola Layanan Teknologi Informasi Menggunakan ITIL versi 3 Domain Service Transition Dan Service Operation Di Pemerintah Kota Bandung,” J. Inf. Syst. Eng. Bus. Intell., vol. 2, no. 2, p. 81, 2016. 
INTENSIF, Vol.4 No.2 August 2020

ISSN: 2580-409X (Print) / 2549-6824 (Online)

DOI: https://doi.org/10.29407/intensif.v4i2.14297

[19] A. Pamurjadi and B. P. P, "Analisis dan Rancangan Manajemen Service Desk di Instansi Pemerintah (Studi Kasus: Badan Litbang Pertanian),” J. IPTEKKOM J. Ilmu Pengetah. Teknol. Inf., vol. 16, no. 1, p. 69, 2014.

[20] ITGI, Board Briefing on IT Governance - 2nd Edition. 2003. 
INTENSIF, Vol.4 No.2 August 2020

ISSN: 2580-409X (Print) / 2549-6824 (Online)

DOI: https://doi.org/10.29407/intensif.v4i2.14297

\section{We Care, We Share}

This is Why You Should Publish With Us

Csinta

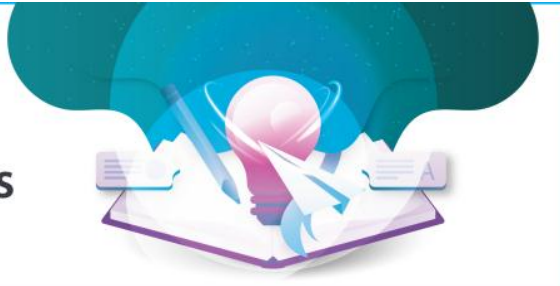

This page is intentionally left blank 